\title{
Nitrate Reverses Severe Nitrite Inhibition of Anaerobic Ammonium Oxidation (Anammox) Activity in Continuously-Fed Bioreactors
}

This work has been published in Environ. Sci. Technol.2016,50(19), 10518-10526;

DOI:10.1021/acs.est.6b01560

\author{
Guangbin Li*1, Reyes Sierra-Alvarez ${ }^{1}$, David Vilcherrez ${ }^{1}$, Stefan Weiss ${ }^{1}$, Callie Gill ${ }^{1}$, \\ Mark J Krzmarzick ${ }^{2}$, Leif Abrell ${ }^{3}$, Jim A. Field ${ }^{1}$ \\ ${ }^{1}$ Department of Chemical and Environmental Engineering, University of Arizona \\ 1133 E. James E. Rogers Way, Tucson, AZ 85721-001, USA \\ ${ }^{2}$ School of Civil and Environmental Engineering, Oklahoma State University \\ 207 Engineering South Stillwater, OK 74078, USA \\ ${ }^{3}$ Department of Chemistry and Biochemistry, University of Arizona, Tucson, AZ \\ 85721-0041, USA \\ ${ }^{4}$ Department of Soil, Water \& Environmental Science, University of Arizona, \\ Tucson, AZ 85721-0041, USA \\ ${ }^{*}$ Corresponding author: Guangbin Li \\ (Tel: +1 520332 4617; E-mail: guangbinli@email.arizona.edu)
}


TOC Art

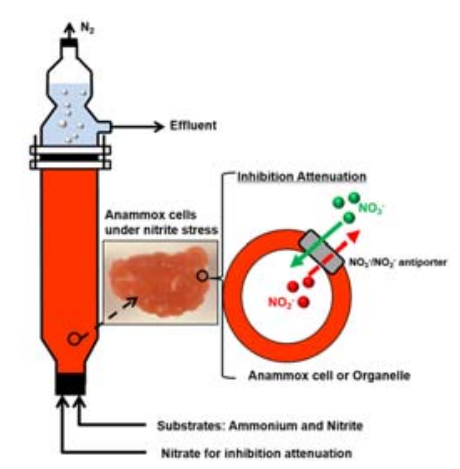

\section{ABSTRACT}

Nitrite $\left(\mathrm{NO}_{2}{ }^{-}\right)$substrate under certain conditions can cause failure of $\mathrm{N}$-removal processes relying on anaerobic ammonium oxidizing (anammox) bacteria.

Detoxification of $\mathrm{NO}_{2}{ }^{-}$can potentially be achieved by using exogenous nitrate $\left(\mathrm{NO}_{3}{ }^{-}\right)$.

In this work, continuous experiments in bioreactors with anammox bacteria closely

related to "Candidatus Brocadia caroliniensis" were conducted to evaluate the effectiveness of short $\mathrm{NO}_{3}{ }^{-}$additions to reverse $\mathrm{NO}_{2}{ }^{-}$toxicity. The results show that a timely $\mathrm{NO}_{3}{ }^{-}$addition immediately after a $\mathrm{NO}_{2}{ }^{-}$stress event completely reversed the $\mathrm{NO}_{2}{ }^{-}$inhibition. This reversal occurs without $\mathrm{NO}_{3}{ }^{-}$being metabolized as evidence by lack of any ${ }^{30} \mathrm{~N}_{2}$ formation from ${ }^{15} \mathrm{~N}_{-} \mathrm{NO}_{3}{ }^{-}$. The maximum recovery rate was observed with $5 \mathrm{mM} \mathrm{NO}_{3}{ }^{-}$added for 3 days; however, slower but significant recovery was also observed with $5 \mathrm{mM} \mathrm{NO}_{3}^{-}$for 1 day or $2 \mathrm{mM} \mathrm{NO}_{3}^{-}$for 3 days. Without $\mathrm{NO}_{3}{ }^{-}$addition, long-term $\mathrm{NO}_{2}{ }^{-}$inhibition of anammox biomass resulted in irreversible damage of the cells. These results suggest that a short duration dose of $\mathrm{NO}_{3}{ }^{-}$to an anammox bioreactor can rapidly restore the activity of $\mathrm{NO}_{2}{ }^{-}$-stressed anammox cells. On the 
basis of the results, a hypothesis about the detoxification mechanism related to narK genes in anammox bacteria is proposed and discussed.

Keywords: Nitrogen removal, Nitrite inhibition, Nitrate, Continuous bioreactors, Detoxification 


\section{INTRODUCTION}

Since anaerobic ammonium oxidation (anammox) was first discovered in the early 1990s, it has been applied as a promising technology to treat ammonium rich wastewaters with low $\mathrm{C}: \mathrm{N}$ ratio. Anammox bacteria utilize nitrite $\left(\mathrm{NO}_{2}^{-}\right)$as an electron acceptor to oxidize ammonium $\left(\mathrm{NH}_{4}{ }^{+}\right)$with $\mathrm{N}_{2}$ gas as the main product and nitrate $\left(\mathrm{NO}_{3}^{-}\right)$as a byproduct. Anammox are chemolithoautotropic bacteria that can provide advantages over the conventional nitrification-denitrification $\mathrm{N}$-removal process due to no need for an external electron donor and lowered aeration requirements $(60 \% \text { saving })^{1}$. Therefore, the application of the anammox process has become widely developed for N-removal in both side- and main-streams of wastewater treatment plants ${ }^{1-3}$.

However, $\mathrm{NO}_{2}^{-}$substrate inhibition of anammox microorganisms has commonly been observed in both lab- and full-scale anammox systems ${ }^{4-6}$. A good understanding of $\mathrm{NO}_{2}^{-}$inhibition to anammox bacteria is still missing and could provide better insight on the measures that can be taken to recover anammox biomass after $\mathrm{NO}_{2}^{-}$inhibition events. Current knowledge indicates that the sensitivity of anammox bacteria to $\mathrm{NO}_{2}^{-}$varies by orders of magnitude $(7-29 \mathrm{mM})$ from experiment to experiment ${ }^{7}$ and the $\mathrm{N}$ species, free nitrous acid or nitrite, responsible for the toxicity is still in debate ${ }^{5,8,9}$. Recent studies indicate that both the cell energy status and $\mathrm{pH}$ are linked to the severity of $\mathrm{NO}_{2}^{-}$inhibition. Anammox cells were reported to show increased sensitivity to $\mathrm{NO}_{2}^{-}$inhibition when pretreated by either starving the cells or pre-incubating the cells in the medium with $\mathrm{NO}_{2}{ }^{-}$alone without 
the electron donating energy substrate, $\mathrm{NH}_{4}{ }^{+5,9,10}$. Additionally, the $\mathrm{pH}$ has a large impact on the sensitivity of anammox cells in response to $\mathrm{NO}_{2}^{-}$toxicity, with the sensitivity increasing substantially as the $\mathrm{pH}$ is lowered from 7.4 to $6.7^{11}$. Moreover, respiration uncouplers, that dissipate the proton gradient and are expected to disrupt energy metabolism of anammox bacteria, were found to sharply enhance the toxicity of $\mathrm{NO}_{2}{ }^{-}$to anammox cells even at $\mathrm{pH}$ values (7.4-7.5) that otherwise are very favorable for anammox $7,12,13$. These results collectively indicate energy is required for anammox bacteria to tolerate $\mathrm{NO}_{2}{ }^{-}$and that energy may be available from a proton gradient to drive transport of $\mathrm{NO}_{2}^{-}$from sensitive regions of anammox cells.

Besides cell energy, we hypothesize that detoxification of $\mathrm{NO}_{2}^{-}$can also be achieved by an alternative mechanism involving the presence of $\mathrm{NO}_{3}{ }^{-}$which facilitates the transport of $\mathrm{NO}_{2}^{-}$from sensitive regions of anammox cells. Firstly, current evidences indicate the presence of NarK protein in the genomes of anammox bacteria such as Candidatus Brocadia sinica (Accession No. KXK2565, NCBI Genbank) ${ }^{14}$ with two potential functions a) $\mathrm{NO}_{3}{ }^{-} / \mathrm{NO}_{2}{ }^{-}$antiporter and b) $\mathrm{NO}_{3}{ }^{-} / \mathrm{H}^{+}$ symporter ${ }^{15-22}$. Secondly, the results obtained from our previous work indicate exogenous $\mathrm{NO}_{3}{ }^{-}$, irrespective of the status of the proton gradient, was able to attenuate $\mathrm{NO}_{2}^{-}$toxicity to anammox cells in batch bioassays. This behavior is consistent with the putative antiporter function of $n a r K$ as a $\mathrm{NO}_{3}{ }^{-} / \mathrm{NO}_{2}{ }^{-}$antiporter in anammox cells ${ }^{7}$.

To further understand the role of $\mathrm{NO}_{3}{ }^{-}$in attenuating $\mathrm{NO}_{2}^{-}$toxicity to anammox bacteria, continuous experiments in upflow anaerobic sludge blanket (UASB) reactors were conducted using granular anammox sludge. The main objective of this study is 
to determine if and how $\mathrm{NO}_{3}{ }^{-}$addition could be used as a measure to restore the activity of nitrite-inhibited anammox biomass in continuous bioreactors, thereby preventing reactor failure. Isotopically labeled $\mathrm{N}$ was utilized to demonstrate that only the anammox reaction was responsible for $\mathrm{N}_{2}$ production and that other potential biological processes (e.g. denitrification) were not responsible for the recovery of $\mathrm{N}_{2}$ production.

\section{MATERIALS AND METHODS}

Biomass. Anammox granular sludge used in this work was originally provided by Paques BV (Balk, The Netherlands) from a full-scale anammox wastewater treatment plant in The Netherlands. A 3-L lab-scale expended granular sludge bed (EGSB) was used to cultivate and maintain the sludge for 5 years before this study. As described in previous work ${ }^{7}$, EGSB was fed with a synthetic medium at a loading rate of $4.0 \mathrm{~g} \mathrm{~N}$ $\mathrm{L}^{-1}$ day $^{-1}$, with a specific anammox activity (SAA) of $0.75 \pm 0.17 \mathrm{~g} \mathrm{~N}_{2}-\mathrm{N}$ g volatile suspended solids (VSS) ${ }^{-1} \mathrm{~d}^{-1}$. The average granule size was $2.2 \pm 0.6 \mathrm{~mm}$ in diameter calculated by image analysis using the software ImageJ. The sludge exhibited a red color which is typical of a highly enriched culture of anammox bacteria ${ }^{23}$, and the experimental molar stoichiometric ratios of $\mathrm{NH}_{4}{ }^{+}$conversion, $\mathrm{NO}_{2}^{-}$removal, and $\mathrm{N}_{2}$ gas and $\mathrm{NO}_{3}{ }^{-}$production are 1.0: 1.38( \pm 0.07$): 1.04( \pm 0.09): 0.25( \pm 0.03)$ which are close to the reported ratios for anammox enrichment cultures 24,25 , with a good balance of nitrogen (around 105\%) (Figures S1 and S2 in Supporting Information). 
Evidence that anammox and not denitrification was predominant process was obtained with ${ }^{15} \mathrm{~N}$ labeled substrates described below.

${ }^{15}$ N Labeling Bioassays. Serum flasks $(25 \mathrm{~mL})$ were supplied with anammox sludge (0.71 VSS L $\left.{ }^{-1}\right)$ and $15 \mathrm{~mL}$ basal mineral medium containing (in $\mathrm{mg} \mathrm{L}^{-1}$ ): $\mathrm{NaH}_{2} \mathrm{PO}_{4} \cdot \mathrm{H}_{2} \mathrm{O}(57.5), \mathrm{CaCl}_{2} \cdot 2 \mathrm{H}_{2} \mathrm{O}(100), \mathrm{MgSO}_{4} \cdot 7 \mathrm{H}_{2} \mathrm{O}(200)$, and $1.0 \mathrm{~mL} \mathrm{~L}^{-1}$ of two trace element solutions ${ }^{9} .25 \mathrm{mM}$ 4-(2-hydroxyethyl)-1-piperazine-ethane sulfonic acid (HEPES) was used as buffer to maintain the $\mathrm{pH}$ of 7.0. The serum flasks were sealed with rubber stoppers and aluminum crimp seals, followed by flushing with helium gas to create anaerobic conditions. Non-labeled/labeled substrates were added in five combinations as follows: a) ${ }^{14} \mathrm{NO}_{2}{ }^{-}+{ }^{14} \mathrm{NH}_{4}+$, b) ${ }^{14} \mathrm{NO}_{2}-+{ }^{15} \mathrm{NH}_{4}{ }^{+}$, c) ${ }^{14} \mathrm{NO}_{2}{ }^{-}+$ ${ }^{14} \mathrm{NH}_{4}{ }^{+}+{ }^{15} \mathrm{NO}_{3}{ }^{-}$, d) ${ }^{14} \mathrm{NH}_{4}{ }^{+}+{ }^{15} \mathrm{NO}_{3}{ }^{-}$, and e) ${ }^{15} \mathrm{NO}_{3}{ }^{-}$, while a group without adding substrate was used as the blank. Finally, bioassays were incubated on a shaker (115 rpm) in a dark and climate controlled room $\left(30 \pm 2{ }^{\circ} \mathrm{C}\right)$. During 10 hours experimental time, gas samples were collected at the beginning and the end of the experiment and analyzed immediately by gas chromatography-mass spectrometry (GC-MS).

Clone Library. A clone library analysis identified the anammox bacteria in the sludge. Sludge DNA was extracted from $100 \mu \mathrm{L}$ of suspended culture with a PowerSoil DNA Isolation Kit (Mo Bio Laboratories, Carlsbad CA). Two PCR methods were used to target near-complete 16S rRNA sequences of anammox bacterial 16S rRNA. One PCR method used primers Pla46F (5'-GGATTAGGCATGCAAGTC-3') ${ }^{26}$ and universal primer 1392R (5'-GACGGGCGGTGTGTACAA-3') ${ }^{27}$ as described by Rich et al. ${ }^{28}$, while the 
second used primers An7F (5'-GGCATGCAAGTCGAACGAGG-3') and An1388R (5'-GCTTGACGGGCGGTGTG-3') ${ }^{29}$. Each PCR reaction $(50 \mu \mathrm{L})$ contained $10 \mathrm{ng}$ of DNA extract, $1.0 \mathrm{mM} \mathrm{MgCl} 2,1 \times \mathrm{DNA}$ GoTaq buffer (Promega, Madison WI), 1.6 mM dNTPs, $1.25 \mu \mathrm{g}$ bovine serum albumin (BSA), $0.62 \mathrm{U}$ of GoTaq DNA polymerase (Promega, Madison WI), and $0.5 \mu \mathrm{M}$ of each primer. Thermocycling conditions were an initial denaturing at $94{ }^{\circ} \mathrm{C}$ for $3 \mathrm{~min}$ followed by 35 cycles of $30 \mathrm{~s}$ at $94{ }^{\circ} \mathrm{C}, 1 \mathrm{~min}$ at $55^{\circ} \mathrm{C}$, and $1 \mathrm{~min}$ at $72{ }^{\circ} \mathrm{C}$ with a final extension of $7 \mathrm{~min}$ at $72{ }^{\circ} \mathrm{C}$. PCR product was analyzed for correct size by gel electrophoresis on a $1 \%$ agarose gel dyed with EnviroSafe Stain (Helixx Technologies, Scarborough ON, Canada), cleaned using the UltraClean PCR Clean-Up Kit (Mo Bio Laboratories, Carlsbad CA) and cloned using the pGEM-T Easy Vector System (Promega, Madison WI). Clones were sequenced with M13 primers in both directions at the DNA/Protein core facility at Oklahoma State University with an ABI Model 3730 Analyzer.

Continuous Bioreactors. Nine UASB reactors $(500 \mathrm{~mL})$ were utilized in three experiments. Each compared three conditions run in parallel. Anammox granular sludge (1.24 $\left.\mathrm{g} \mathrm{VSS} \mathrm{L}^{-1}\right)$ was inoculated in each bioreactor operated in a dark and temperature controlled room $\left(30 \pm 2{ }^{\circ} \mathrm{C}\right)$. The same basal mineral medium (described above) was fed into the bioreactor at a constant flow rate of $1.39 \mathrm{~mL} \mathrm{~min}^{-1}$ corresponding to a hydraulic retention time (HRT) of $0.25 \mathrm{~d}$. But, the feeding medium in bioreactors contained $1 \mathrm{~g} \mathrm{~L}^{-1} \mathrm{NaHCO}_{3}$ rather than HEPES, and $\mathrm{N}$ compounds, including $\mathrm{NO}_{2}{ }^{-}, \mathrm{NH}_{4}^{+}$and $\mathrm{NO}_{3}^{-}$, were fed into the reactors according to the designated 
experimental plan described later. A gas mixture, $\mathrm{He}: \mathrm{CO}_{2}(80: 20$, v:v), was used to flush the medium before use to make it anaerobic and providing a $\mathrm{pH}$ of $7.0 \pm 0.2$.

The feeding of $\mathrm{N}$ compounds $\left(\mathrm{NO}_{2}^{-}, \mathrm{NH}_{4}{ }^{+}\right.$and $\left.\mathrm{NO}_{3}^{-}\right)$in each bioreactor varied in three experiments followed a designed plan shown in Table 1 and described below. During all experiments, concentrations of $9.3 \mathrm{mM} \mathrm{NO}_{2}{ }^{-}$and $7.7 \mathrm{mM} \mathrm{NH}_{4}{ }^{+}$were selected on the basis of successful operation of continuous bioreactors reported in the previous work ${ }^{7,10,37}$. A 4-day interruption of $\mathrm{NH}_{4}{ }^{+}$(thus a 4 days exposure to $\mathrm{NO}_{2}^{-}$ only) was applied to inhibit the anammox bacteria in the designated column based on results from an earlier study ${ }^{10}$ that showed a complete inhibition of anammox activity was achieved under the selected condition (4 days exposure to $9.3 \mathrm{mM} \mathrm{NO}_{2}{ }^{-}$at $\mathrm{pH}$ 7.0) mentioned above.

Experiment 1 (E1, 35 days): As shown in Table 1, $\mathrm{NO}_{2}{ }^{-}$and $\mathrm{NH}_{4}{ }^{+}$were always supplied into R1 as the control reactor during the entire operation period. As comparison, a 4-day interruption of $\mathrm{NH}_{4}{ }^{+}$was applied in $\mathrm{R} 2$ and $\mathrm{R} 3$ from day 14 to promote severe $\mathrm{NO}_{2}{ }^{-}$inhibition to anammox bacteria. Thereafter, $\mathrm{NH}_{4}{ }^{+}$was supplied again to $\mathrm{R} 2$ and $\mathrm{R} 3$. In $\mathrm{R} 2,5.0 \mathrm{mM} \mathrm{NO}^{-}{ }^{-}$was selected based on a previous work ${ }^{7}$ and additionally added immediately after the $\mathrm{NH}_{4}{ }^{+}$feeding interruption for 3 days (days 18-20). The goal was to evaluate the feasibility of using $\mathrm{NO}_{3}^{-}$to reverse $\mathrm{NO}_{2}{ }^{-}$ inhibited anammox bacteria. In $\mathrm{R} 3,5.0 \mathrm{mM} \mathrm{NO}_{3}{ }^{-}$was also added but instead of adding it immediately after the $\mathrm{NH}_{4}{ }^{+}$feeding interruption, it was instead added 10 days after that interruption ended for 4 days (days 28-32) to determine if the delayed addition of $\mathrm{NO}_{3}{ }^{-}$was still effective in reversing the $\mathrm{NO}_{2}{ }^{-}$inhibited anammox biomass. 
Experiment 2 (E2, 32 days): The same feeding plan was applied in $\mathrm{R} 4$ as the control reactor (R1) described above. The feeding of $\mathrm{NH}_{4}{ }^{+}$was interrupted for 4 days (days 17-20) in $\mathrm{R} 5$ and $\mathrm{R} 6$ (shown in Table 1 E2). After $\mathrm{NH}_{4}{ }^{+}$was resupplied on day 21, together with different concentrations of $\mathrm{NO}_{3}{ }^{-}(2.0 \mathrm{mM}$ in $\mathrm{R} 5$ and $3.3 \mathrm{mM}$ in R6) that were fed into reactors for 3 days (days 21-23) with the objective to determine the role of $\mathrm{NO}_{3}{ }^{-}$concentration on reversing the $\mathrm{NO}_{2}^{-}$inhibition.

Experiment 3 (E3, 30 days): $\mathrm{R} 7$ was also operated the same as the control reactor (R1). As shown in Table $1 E 3, \mathrm{R} 8$ was operated with a 4-day interruption of $\mathrm{NH}_{4}{ }^{+}$that ran from days 17 to 20 . Subsequently after the interruption, $5.0 \mathrm{mM} \mathrm{NO}_{3}^{-}$ was provided but the $\mathrm{NO}_{2}^{-}$supply was cut off in order to confirm there was no significant $\mathrm{N}_{2}$ production due to denitrification. From day 27 onwards, $\mathrm{NO}_{2}^{-}$replaced $\mathrm{NO}_{3}{ }^{-}$to confirm that only the anammox reaction was responsible for the observed $\mathrm{N}_{2}$ production. $\mathrm{R} 9$ also had a similar interruption of $\mathrm{NH}_{4}{ }^{+}$feeding as performed in $\mathrm{R} 2$, but after the interruption, $5.0 \mathrm{mM} \mathrm{NO}_{3}{ }^{-}$was supplied for only 24 hours aiming to determine if a short exposure of $\mathrm{NO}_{3}^{-}$is sufficient to reverse the $\mathrm{NO}_{2}^{-}$inhibition.

The performance of UASB reactors was estimated by the evolution of the daily $\mathrm{N}_{2}$ production. The measurement of $\mathrm{N}_{2}$ gas production relied on a liquid displacement system in which a $2 \%(\mathrm{w} / \mathrm{v}) \mathrm{NaOH}$ solution was used to remove the interference caused by $\mathrm{CO}_{2}$. Meanwhile, batch activity tests were periodically conducted in $25 \mathrm{~mL}$ serum flasks with $15 \mathrm{~mL}$ liquid volume by retrieving granular sludge from each bioreactor. The medium, buffer system and operation used in activity test were as same as previously described in the ${ }^{15} \mathrm{~N}$ labeling bioassays except 
that regular (non-labeled) $\mathrm{NO}_{2}{ }^{-}$and $\mathrm{NH}_{4}{ }^{+}$were supplemented. Gas samples $(100 \mu \mathrm{L})$ were also collected regularly to measure the specific anammox activity (SAA). In addition to $\mathrm{N}_{2}$ measurement, ionic species of $\mathrm{N}$-coumpounds $\left(\mathrm{NO}_{2}^{-}, \mathrm{NH}_{4}^{+}\right.$, and $\left.\mathrm{NO}_{3}{ }^{-}\right)$ were also monitored on a routine basis.

Analytical methods. $\mathrm{NO}_{2}^{-}, \mathrm{NH}_{4}{ }^{+}$and $\mathrm{NO}_{3}{ }^{-}$in liquid samples were measured by suppressed conductivity ion chromatography using a dual line Dionex IC-3000 system (Dionex, Sunnyvale, CA). N2 was analyzed by using an Agilent 7890 gas chromatograph (Agilent Technologies, Santa Clara, CA). The configuration and parameter settings of GC and IC were according to previous work ${ }^{7}$. The $\mathrm{pH}$, TSS and VSS were determined according to standard methods ${ }^{30}$.

$\mathrm{N}_{2}$ isotopologues $\left({ }^{14} \mathrm{~N}^{14} \mathrm{~N},{ }^{14} \mathrm{~N}^{15} \mathrm{~N}\right.$, and $\left.{ }^{15} \mathrm{~N}^{15} \mathrm{~N}\right)$ were analyzed by GC-MS (7890 gas chromatograph, Agilent Technologies, Santa Clara, CA, USA with a Quattro micro triple quadrupole mass spectrometer, Waters Corp., Milford, MA, USA) equipped with a DB-5MS capillary column (30 m length, $250 \mu \mathrm{m}$ inner diameter, $0.25 \mu \mathrm{m}$ thickness; Agilent Technologies). Ultra-high purity (99.999\%) $\mathrm{He}$ was used as a carrier gas at a constant flow rate of $3.9 \mathrm{~mL} \mathrm{~min}^{-1}$. The oven temperature program began at $30^{\circ} \mathrm{C}$ for $5 \mathrm{~min}$ before increasing at $40{ }^{\circ} \mathrm{C} \min ^{-1}$ up to $110^{\circ} \mathrm{C}$ where it was held for $5 \mathrm{~min}$. A $5 \mu \mathrm{L}$ injection with a split ratio of 1,000 was made using a gas-tight syringe with a single-taper glass-wool inlet liner.

Data processing. $\delta$ values previously described ${ }^{31}$ were modified to express the ratio of $\mathrm{N}_{2}$ isotopomers detected in samples and blank group. For instance, $\delta^{14} \mathrm{~N}^{15} \mathrm{~N}$ 
value $=\left[\left({ }^{14} \mathrm{~N}^{15} \mathrm{~N}:{ }^{14} \mathrm{~N}^{14} \mathrm{~N}\right)\right.$ sample $]:\left[\left({ }^{14} \mathrm{~N}^{15} \mathrm{~N}:{ }^{14} \mathrm{~N}^{14} \mathrm{~N}\right)\right.$ blank $]$. The specific anammox activity (SAA) was calculated from the time course of $\mathrm{N}_{2}$ production and expressed as g $\mathrm{N}_{2}-\mathrm{N}$ $\mathrm{g}^{-1} \mathrm{VSS} \mathrm{d}^{-1}$. Sequences from the clone library were analyzed with MEGA 6.06 software ${ }^{32}$. Plasmid and primer sequence data were trimmed from sequences. For each clone, the forward and reverse sequences were aligned to form a single consensus sequence. Sequences were then analyzed for phylogeny using NCBI's BLASTN, and the most closely related full 16S rRNA sequences were loaded into MEGA for alignment. Clones and related sequences from BLAST were aligned using ClustalW, and analyzed phylogenetically using the Neighbor-Joining method ${ }^{33}$ with bootstrap testing (500 replicates) ${ }^{34}$ and with evolutionary distances computed with the Maximum Composite Likelihood method ${ }^{35}$. The sequences obtained from the clone library have been deposited in the GenBank database (http://www.ncbi.nlm.nih.gov) under the accession numbers KU883238 - KU883255.

\section{RESULTS AND DISCUSSION}

Anammox as the Dominant Microbial Process. The dominance of the anammox reaction in this work was confirmed with both ${ }^{15} \mathrm{~N}$ labeling test, stoichiometry of the reaction and the dependence of $\mathrm{N}_{2}$ production occurring only when both $\mathrm{NO}_{2}{ }^{-}$and $\mathrm{NH}_{4}{ }^{+}$were fed together in the continuous experiments. Also, the presence of common anammox bacteria was confirmed with a clone library which found sequences to be $99 \%$ identical along the $16 \mathrm{~S}$ rRNA gene with "Candidatus Brocadia carolinienis" strain NRRL B-50286 ${ }^{36}$ (Figure S3). 
Results from ${ }^{15} \mathrm{~N}$ labeling bioassays provided the conclusive evidence that anammox reaction was the predominant microbial process while denitrification of $\mathrm{NO}_{3}{ }^{-}$was negligible. As shown in Figure 1, the accumulation of ${ }^{29} \mathrm{~N}_{2}\left({ }^{14} \mathrm{~N}^{15} \mathrm{~N}\right)$ was observed in the group fed with ${ }^{15} \mathrm{NH}_{4}{ }^{+}$and ${ }^{14} \mathrm{NO}_{2}^{-}$, but no increase occurred in ${ }^{30} \mathrm{~N}_{2}$ $\left({ }^{15} \mathrm{~N}^{15} \mathrm{~N}\right)$ production in the headspace in the group fed with ${ }^{15} \mathrm{NO}_{3}{ }^{-}$, as the indicator of denitrification potential. Also, on the basis of the analysis of $\mathrm{N}$ compounds $\left(\mathrm{N}_{2}, \mathrm{NO}_{2}^{-}\right.$, $\mathrm{NH}_{4}{ }^{+}$and $\mathrm{NO}_{3}{ }^{-}$) in both influent and effluent in continuous bioreactors calculation of $\mathrm{N}$ recovery showed a consistent reaction stoichiometry comparable to the reported values for anammox enrichment culture ${ }^{24,25}$. As an example, results of R2 indicated that the molar stoichiometry of the reaction in UASB expressed as molar stoichiometric ratios of $\mathrm{NO}_{2}{ }^{-}$removal, $\mathrm{N}_{2}$ gas and $\mathrm{NO}_{3}{ }^{-}$production to $\mathrm{NH}_{4}{ }^{+}$ consumption were $1.38( \pm 0.07): 1.04( \pm 0.09)$ : $0.25( \pm 0.03)$, respectively, with a balance of nitrogen of around $105 \%$ (Figure S1).

$\mathrm{NO}_{3}{ }^{-}$Attenuation of $\mathrm{NO}_{2}^{-}$Toxicity to Anammox Bacteria in UASB. As shown in Figure 2 periods 2 of R2 and R3, no $\mathrm{N}_{2}$ gas production was observed after interrupting the $\mathrm{NH}_{4}{ }^{+}$feeding and the concentration of $\mathrm{NO}_{2}{ }^{-}$detected in effluent increased from undetectable level to $9.0 \mathrm{mM}$ within 1 day (Figure S4). When the $\mathrm{NH}_{4}^{+}$feeding was resumed (after a 4-day interruption of $\mathrm{NH}_{4}^{+}$), $\mathrm{N}_{2}$ gas production was still negligible (Figure 2 periods 3 to 4 of $\mathrm{R} 3$ ) and $\mathrm{NO}_{2}{ }^{-}$and $\mathrm{NH}_{4}{ }^{+}$accumulated in the bioreactor effluent with the detected concentration of $9.0 \mathrm{mM} \mathrm{NO}_{2}{ }^{-}$and $7.5 \mathrm{mM}$ $\mathrm{NH}_{4}{ }^{+}$, respectively (Figure S4). Therefore, exposure of anammox bacteria to $\mathrm{NO}_{2}{ }^{-}$ alone by interrupting the $\mathrm{NH}_{4}{ }^{+}$feeding caused failure of the anammox UASB at $\mathrm{pH}$ 
7.0, which is consistent with previous research in batch tests that also showed the enhancement of inhibition with the time of pre-exposure of anammox bacteria to $\mathrm{NO}_{2}^{-}$ 7, 10,37. A parallel run control reactor $(\mathrm{R} 1)$, without the $\mathrm{NH}_{4}{ }^{+}$feeding interruption, continued to effectively convert $\mathrm{NO}_{2}{ }^{-}$and $\mathrm{NH}_{4}{ }^{+}$to $\mathrm{N}_{2}$ gas during the same period (Figure 2). Current knowledge of $\mathrm{NO}_{2}^{-}$stress indicates that accumulation of $\mathrm{NO}_{2}^{-}$in sensitive regions within anammox cells causes toxicity and evolution of NO gas which indicates a disturbance in the metabolic steps of $\mathrm{NO}_{2}^{-}$reduction ${ }^{11,38}$.

Results obtained from R2 (Figure 2) indicated that a timely short-term (3 days) addition of $\mathrm{NO}_{3}{ }^{-}$(period 3), immediately following the interruption of $\mathrm{NH}_{4}^{+}$feeding causing $\mathrm{NO}_{2}^{-}$stress (period 2), enabled rapid recovery of the inhibited $\mathrm{N}_{2}$ production capacity of the anammox UASB. This was consistent with decreasing concentrations of $\mathrm{NO}_{2}{ }^{-}$and $\mathrm{NH}_{4}{ }^{+}$in the effluent of $\mathrm{R} 2$. After $\mathrm{NO}_{3}{ }^{-}$and $\mathrm{NH}_{4}{ }^{+}$were supplied into $\mathrm{R} 2$, concentrations of $\mathrm{NO}_{2}^{-}$found in the effluent decreased from $9.0 \mathrm{mM}$ to undetectable level within 4 days, while concentrations of $\mathrm{NH}_{4}{ }^{+}$found in the effluent decreased from $7.0 \mathrm{mM}$ to $1.0 \mathrm{mM}$ in the same time period. The concentration of $\mathrm{NO}_{3}{ }^{-}$found in the system was close to $4.5 \mathrm{mM}$ in period 3 and then decreased to $1.5 \mathrm{mM}$ in period 4 as the by-product of anammox reaction (Figure S4). Our previous study also demonstrated a similar recovery of $\mathrm{NO}_{2}^{-}$-stressed anammox biomass in response to $\mathrm{NO}_{3}{ }^{-}$addition in batch experiments ${ }^{7}$. The performance of $\mathrm{R} 2$ recovered to normal levels (compared to control bioreactor, R1) in period 4 and the stoichiometry calculated according to the data obtained in period 4 to 6 demonstrated that the dominant reaction is still anammox (Figure S1). 
$\mathrm{NO}_{3}{ }^{-}$addition is hypothesized to have facilitated the functioning of $\mathrm{NO}_{3}{ }^{-} / \mathrm{NO}_{2}{ }^{-}$ antiporter activity, required as a detoxification mechanism of $\mathrm{NO}_{2}^{-}$stress. This hypothesis is supported by the fact that added $\mathrm{NO}_{3}{ }^{-}$was not directly metabolized to $\mathrm{N}_{2}$ in the anammox granular sludge. As shown in Figure 1, labeling bioassays indicated that the $\mathrm{N}_{2}$ gas production did not come from the $\mathrm{NO}_{3}{ }^{-}$metabolism because no accumulation of ${ }^{15} \mathrm{~N}_{2}$ was found in the group fed with ${ }^{15} \mathrm{NO}_{3}-{ }^{14} \mathrm{NO}_{2}{ }^{-}$and ${ }^{14} \mathrm{NH}_{4}{ }^{+}$. Therefore, effect of $\mathrm{NO}_{3}{ }^{-}$addition on recovery of $\mathrm{NO}_{2}{ }^{-}$inhibited anammox process cannot be explained by metabolism of $\mathrm{NO}_{3}{ }^{-}$to $\mathrm{N}_{2}$. Secondly, since the $\mathrm{pH}(7.0 \pm 0.2)$ was well controlled in bioreactors during this experiment, the performance recovery of the continuous reactors was not caused by $\mathrm{pH}$ changes they may have impacted the proton gradient. Also, previous work examined the potential relationship between proton gradient and attenuation of $\mathrm{NO}_{2}^{-}$inhibition by $\mathrm{NO}_{3}^{-}$by utilizing the respiratory uncoupler, carbonyl cyanide m-chlorophenyl hydrazine (CCCP), and the results indicated that $\mathrm{NO}_{3}{ }^{-}$attenuation works regardless of the proton gradient status ${ }^{7}$. The results discussed above collectively show that $\mathrm{NO}_{3}{ }^{-}$attenuation of $\mathrm{NO}_{2}{ }^{-}$inhibition to anammox process relies on a process in which $\mathrm{NO}_{3}{ }^{-}$presence enables a hypothesized translocation of $\mathrm{NO}_{2}{ }^{-}$accumulated in sensitive regions of the cells to less sensitive regions in or outside the cells without any reliance on a proton gradient. Compared with other transporters ( $\operatorname{nir} C$ and $f o c A$ ) involving $\mathrm{NO}_{2}^{-}$transport discovered in anammox cells ${ }^{17,20,21}$, arK type II with the function of $\mathrm{NO}_{3}{ }^{-} / \mathrm{NO}_{2}{ }^{-}$antiporter is the only transporter function meeting the conditions witnessed in this study ${ }^{14-22}$. 
The timing of the $\mathrm{NO}_{3}{ }^{-}$addition was critical to successfully reversing the nitrite-inhibited anammox biomass. In $\mathrm{R} 2, \mathrm{NO}_{3}{ }^{-}$was added immediately after the interruption in the $\mathrm{NH}_{4}{ }^{+}$feeding. As indicated above, this resulted in rapid reversal of $\mathrm{NO}_{2}{ }^{-}$inhibition. In stark contrast, a 10-day delay in the addition of $\mathrm{NO}_{3}^{-}$in $\mathrm{R} 3$ (period 5, Figure 2) after the interruption in the $\mathrm{NH}_{4}{ }^{+}$feeding was completely ineffective in reversing the $\mathrm{NO}_{2}^{-}$inhibition. Although the biomass was only exposed for 4 days to $\mathrm{NO}_{2}{ }^{-}$alone during the $\mathrm{NH}_{4}{ }^{+}$feeding interruption in period 2 and subsequently fed with the energy substrate, $\mathrm{NH}_{4}{ }^{+}$, for the next 10 days (periods 3-4), it seems that nonetheless the cells did not overcome the $\mathrm{NO}_{2}{ }^{-}$stress and permanent damage had occurred such that a late addition of $\mathrm{NO}_{3}{ }^{-}$to cause that the hypothesized translocation of $\mathrm{NO}_{2}^{-}$was no longer effective. The results of $\mathrm{R} 3$ indicate the importance of a timely $\mathrm{NO}_{3}{ }^{-}$addition immediately after a $\mathrm{NO}_{2}{ }^{-}$stress event. It constitutes the difference between a rapid reversal of $\mathrm{NO}_{2}^{-}$inhibition or permanent inactivation of the anammox biomass.

Effect of Added $\mathrm{NO}_{3}{ }^{-}$Concentration. Our previous work carried out in batch bioassays showed that the attenuation of $\mathrm{NO}_{2}{ }^{-}$inhibition is impacted by the $\mathrm{NO}_{3}{ }^{-}$ concentration ${ }^{7}$. Consistent with the work in batch experiments, here too in the continuous experiments, a stronger $\mathrm{NO}_{3}{ }^{-}$gradient created by supplying higher $\mathrm{NO}_{3}{ }^{-}$ concentrations shortened the time required to reverse $\mathrm{NO}_{2}^{-}$inhibition of anammox bacteria in continuous reactors back to normal $\mathrm{N}_{2}$ productivity. Three different $\mathrm{NO}_{3}{ }^{-}$ concentrations $(2.0,3.3$ and $5.0 \mathrm{mM})$ were tested in three reactors in two experiments (shown in Figure 2 R2 and Figure 3 R5 and R6, respectively). The 2.0 and $3.3 \mathrm{mM}$ 
$\mathrm{NO}_{3}{ }^{-}$concentrations tested in experiment 2 were compared with $5.0 \mathrm{mM}$ tested in experiment 1 because the protocol (except $\mathrm{NO}_{3}{ }^{-}$concentration) used in two experiments were the same and the behavior showed in both experiments were consistent. After anammox granular sludge was inhibited by a 4-day interruption of $\mathrm{NH}_{4}{ }^{+}$feeding, $\mathrm{R} 5$ was subsequently exposed for 3 days to $2.0 \mathrm{mM} \mathrm{NO}_{3}{ }^{-}$(Figure 3 period 3). It took 6 days after the start of the $\mathrm{NO}_{3}{ }^{-}$exposure before the $\mathrm{N}_{2}$ gas production resumed (Figure 3 period 4). From that point onwards the anammox $\mathrm{N}_{2}$ productivity recovery occurred at a rate of approximately 15 additional $\mathrm{mL}$ of $\mathrm{N}_{2}$ production per day. Corresponding to that, the concentration of $\mathrm{NO}_{2}{ }^{-}$and $\mathrm{NH}_{4}{ }^{+}$ detected in effluent decreased from 9.0 and $7.3 \mathrm{mM}$ to 6.2 and $5.7 \mathrm{mM}$, respectively, in period 4 (Figure S5). By the end of the experiment, the R5 had not yet achieved the normal daily $\mathrm{N}_{2}$ production performance compared to the control reactors ( $\mathrm{R} 1$ and R4), but R5 may very well have been on track to do so as there was still a steady linear increase in $\mathrm{N}_{2}$ productivity at the end of the experiment. R6 and R2 were operated the same as R5 except $3.3 \mathrm{mM}$ (Figure 3) or $5.0 \mathrm{mM} \mathrm{NO}_{3}^{-}$(Figure 2), respectively, was used instead of $2.0 \mathrm{mM}$. In the case of $\mathrm{R} 6, \mathrm{~N}_{2}$ production resumed after 3 days since the start of the $\mathrm{NO}_{3}{ }^{-}$exposure. From that point onwards the $\mathrm{N}_{2}$ productivity recovery occurred at a rate of approximately 37 additional $\mathrm{mL}$ of $\mathrm{N}_{2}$ production per day. By the end of the experiment the daily $\mathrm{N}_{2}$ production was very close to the values in the control reactors (R1 and R4). In comparison, a productivity recovery rate of 82 additional $\mathrm{mL}$ of $\mathrm{N}_{2}$ production per day was detected in $\mathrm{R} 2$ after 1 day since the start of the $\mathrm{NO}_{3}{ }^{-}$exposure (Figure 4). The incremental rate of $\mathrm{N}_{2}$ 
productivity increase per day during the recovery promoted by $\mathrm{NO}_{3}{ }^{-}$was highly positively correlated to the $\mathrm{NO}_{3}{ }^{-}$concentration. However, the previous work in batch bioassays showed that, at $\mathrm{pH} 7.0$, the toxicity caused by incubating anammox cells in $7.1 \mathrm{mM} \mathrm{NO}_{2}^{-}$for $4 \mathrm{~h}$ pre-exposure was fully attenuated with $0.85 \mathrm{mM} \mathrm{NO}_{3}{ }^{-}$and half of the attenuation capacity was obtained at a very low concentration of $0.23 \mathrm{mM} \mathrm{NO}_{3}^{-}$ ${ }^{7}$. Meanwhile, addition of large excesses of $\mathrm{NO}_{3}{ }^{-}$modestly inhibited anammox activity, which is most likely due to osmotic effect of the salts ${ }^{7}$. Therefore, both the saturation of the attenuation response and potential inhibitory impact caused by high salinity limited the further improvement in activity with even higher $\mathrm{NO}_{3}{ }^{-}$ concentrations ${ }^{7}$. On the other hand, the lag phase in days until the recovery started after exposing anammox biomass to $\mathrm{NO}_{3}{ }^{-}$, was highly negatively correlated with the $\mathrm{NO}_{3}{ }^{-}$concentration (Figure 4).

An $\mathrm{NO}_{3}^{-}$gradient created by supplying $\mathrm{NO}_{3}^{-}$is a requirement in the hypothesized mechanism of $\mathrm{NO}_{2}{ }^{-}$detoxification in anammox process. The presence of ladderane lipids found in anammox anammoxsome membrane enables anammox cells to acquire a strong resistance to free passage of charged molecule ${ }^{39}$, which makes it possible to create and maintain a strong $\mathrm{NO}_{3}{ }^{-}$gradient. Previous work studied the importance of the $\mathrm{NO}_{3}{ }^{-}$gradient by dissipating $\mathrm{NO}_{3}{ }^{-}$gradient across the cellular membranes by soaking anammox cells in an $\mathrm{NO}_{3}^{-}$solution for 3.1 days. The inability of $\mathrm{NO}_{3}^{-}$ addition to reverse the $\mathrm{NO}_{2}^{-}$stress when the $\mathrm{NO}_{3}{ }^{-}$gradient is dissipated clearly indicates the importance that the $\mathrm{NO}_{3}-$ gradient is maintained in the correct direction ${ }^{7}$. Accordingly, the $\mathrm{NO}_{3}{ }^{-}$gradient built up by supplying exogenous $\mathrm{NO}_{3}{ }^{-}$is considered 
as one of two most important requirements to achieve attenuation of $\mathrm{NO}_{2}-$ inhibition by $\mathrm{NO}_{3}{ }^{-}$. The other requirement is the presence of the $\mathrm{NO}_{3}{ }^{-} / \mathrm{NO}_{2}{ }^{-}$antiporter activity.

A key question is whether a short term supply of $\mathrm{NO}_{3}{ }^{-}$is sufficient to reverse $\mathrm{NO}_{2}^{-}$inhibition. The shorter the duration of the supply, the lower the risk would be of accidently dissipating the $\mathrm{NO}_{3}^{-}$gradient. As shown in Figure 5, exposure of an $\mathrm{NO}_{2}^{-}$ stressed bioreactor (R9) to $5.0 \mathrm{mM} \mathrm{NO}^{-}{ }^{-}$addition was carried out for just 1 day (at start of period 3). The recovery of $\mathrm{NO}_{2}^{-}$stress started after a 1 day lag, with a maximum rate of approximately 56 additional $\mathrm{mL}$ of $\mathrm{N}_{2}$ production per day. Complete recovery with daily $\mathrm{N}_{2}$ production comparable to the control reactors ( $\mathrm{R} 1$, $\mathrm{R} 4$ and R7) were observed within 6 days of starting the $\mathrm{NO}_{3}{ }^{-}$exposure. $\mathrm{The}_{2}$ production recovery was consistent with the observation that the concentrations of $\mathrm{NO}_{2}{ }^{-}$and $\mathrm{NH}_{4}{ }^{+}$found in effluent decreased and were undetectable after 7 days (Figure S6). Previous batch experiment also showed that at $\mathrm{pH}$ 7.0, exposure to $\mathrm{NO}_{3}{ }^{-}$for 2.2 hours was enough to recover $\mathrm{NO}_{2}^{-}$inhibited cells and extending the incubation time did not show any apparent improvement of the recovery ${ }^{7}$.

In $\mathrm{R} 8$ (Figure 5), $\mathrm{NO}_{3}{ }^{-}$and $\mathrm{NH}_{4}{ }^{+}$were supplemented for 7 days (period 3) after a 4-day interruption of $\mathrm{NH}_{4}^{+}($period 2$)$ to investigate whether denitrifying bacteria enrichment could be responsible for the $\mathrm{N}_{2}$ gas production. The lack of any $\mathrm{N}_{2}$ production during period 3 confirms that no significant denitrification enrichment was occurring in the time scale of the $\mathrm{NO}_{3}{ }^{-}$exposure used in this study. Likewise the immediate restoration of $\mathrm{N}_{2}$ production upon resupplying $\mathrm{NO}_{2}^{-}$instead of $\mathrm{NO}_{3}^{-}$with $\mathrm{NH}_{4}{ }^{+}$confirmed the dominance of anammox as the main microbial process. This was 
further supported by checking the N-balance and stoichiometry in period 4 of R8 (Figure S2).

\section{Activity Test Consistent with the Performance of Bioreactors Analyzed on}

the Basis of Gas Production. To further confirm the $\mathrm{N}_{2}$ production capacity of continuous bioreactors, anammox granular sludge was periodically retrieved from nine bioreactors, and the specific anammox activity (SAA) in each period was evaluated by conducting batch bioassays. As shown in Figure 6, the biomass in the control bioreactors (R1, R4, and R7) had high SAA during the experimental periods. When the biomass was exposed to a 4-day interruption of $\mathrm{NH}_{4}^{+}$(thus exposed to $\mathrm{NO}_{2}^{-}$ alone), the anammox biomass in all bioreactors (except control bioreactors, R1, R4 and R7) completely lost their activity and remained inhibited. A recovery in SAA after the $\mathrm{NH}_{4}{ }^{+}$feed interruption only occurred if $\mathrm{NO}_{3}{ }^{-}$was supplied in a timely fashion (R2, R5, R6, R9, Figures 2, 3, and 5). The anammox granular biomass retrieved from the bioreactors with the $\mathrm{NO}_{3}{ }^{-}$supplied immediately after the 4-day interruption of $\mathrm{NH}_{4}{ }^{+}$had significantly increased SAA obtained from biomass in $\mathrm{R} 2$ treated for 3 days with $5.0 \mathrm{mM} \mathrm{NO}_{3}{ }^{-}$and $\mathrm{R} 6$ treated for 3 days with $3.3 \mathrm{mM} \mathrm{NO}^{-}{ }^{-}$had SAAs of 0.66 and $0.55 \mathrm{~g} \mathrm{~N}_{2}-\mathrm{N} \mathrm{g}^{-1} \mathrm{VSS} \mathrm{d}^{-1}$, respectively. Moreover, biomass from R9 treated for 1 day with $5.0 \mathrm{mM} \mathrm{NO}_{3}{ }^{-}$immediately after the $\mathrm{NH}_{4}{ }^{+}$feed interruption also had fully recovered SAA of $0.86 \mathrm{~g} \mathrm{~N}_{2}-\mathrm{N} \mathrm{g}^{-1} \mathrm{VSS} \mathrm{d}^{-1}$ (Figure 6) after the $\mathrm{NO}_{2}{ }^{-}$ inhibition. For the sake of comparison, the SAA following the feed interruption of $\mathrm{NH}_{4}{ }^{+}$was only $0.01 \mathrm{~g} \mathrm{~N}_{2}-\mathrm{N} \mathrm{g}^{-1} \mathrm{VSS} \mathrm{d}^{-1}$ when $\mathrm{NO}_{3}^{-}$was not added in a timely fashion (R3 in Figure 2). The anammox granular sludge from R5 which was exposed to 2.0 
$\mathrm{mM} \mathrm{NO}_{3}{ }^{-}$only had a poor restoration of the SAA to $0.06 \mathrm{~g} \mathrm{~N}_{2}-\mathrm{N} \mathrm{g}^{-1} \mathrm{VSS} \mathrm{d}^{-1}$ by day

28. This is consistent with low $\mathrm{N}_{2}$ productivity at the onset of the slow recovery in $\mathrm{R} 2$.

Implications. Together with the previous work conducted in batch bioassays ${ }^{7}$, consistent results were obtained that exogenous $\mathrm{NO}_{3}^{-}$is able to rapidly recover anammox cells from severe $\mathrm{NO}_{2}^{-}$inhibition. The presence of narK genes in anammox bacteria ${ }^{14}$ indicates two potential functions of $\mathrm{NO}_{3}{ }^{-} / \mathrm{NO}_{2}{ }^{-}$antiporter and $\mathrm{NO}_{3}{ }^{-} / \mathrm{H}^{+}$ symporter. If the antiporter is indeed the activity of NarK proteins in our anammox culture, it could explain the alternative $\mathrm{NO}_{2}{ }^{-}$detoxification system resulting from short term exogenous $\mathrm{NO}_{3}{ }^{-}$additions that functions independently of the cell energy status. Therefore, $\mathrm{NO}_{3}{ }^{-}$addition can reactivate anammox bacteria experiencing severe $\mathrm{NO}_{2}{ }^{-}$stress. However, a timely $\mathrm{NO}_{3}{ }^{-}$addition to relieve $\mathrm{NO}_{2}{ }^{-}$stress is necessary because long-term $\mathrm{NO}_{2}^{-}$inhibition of anammox biomass is expected to result in irreversible damage of the cells (and permanent failure of the anammox bioreactors) which cannot be reactivated by delayed $\mathrm{NO}_{3}{ }^{-}$addition. $\mathrm{NO}_{3}{ }^{-}$could be used to reactivate sludge after an accidental interruption of $\mathrm{NH}_{4}^{+}$feeding or after a starvation period due to shipment. Also, $\mathrm{NO}_{3}{ }^{-}$could be introduced into anammox system treating seasonal wastewater (e.g., agro-industrial wastewater) after a long period with low/without feeding ${ }^{40}$. However, the period in which $\mathrm{NO}_{3}{ }^{-}$could be used must be limited to avoid dissipating the $\mathrm{NO}_{3}{ }^{-}$gradient (potentially occurring after long term $\mathrm{NO}_{3}^{-}$exposure). 


\section{AUTHOR INFORMATION}

\section{Corresponding Author}

* Phone: +1-520-332-4617; Fax: +1-520-621-6048; Email:

guangbinli@email.arizona.edu

\section{Present Address}

Department of Chemical and Environmental Engineering, University of Arizona,

1133 E. James E. Rogers Way, Tucson, AZ 85721-001, USA

Notes

The authors declare no competing financial interest.

\section{ACKNOWLEDGEMENTS}

This work was supported by the University of Arizona Water Sustainability Program, and the National Science Foundation (Contract CBET-1234211).

\section{SUPPORTING INFORMATION AVAILABLE}

Supplementary materials and data associated with this article are provided in

Supporting Information. 
Figure S1: reaction stoichiometry and N-balance calculated on the basis of the data of period 4-6 in R2; Figure S2: reaction stoichiometry and N-balance calculated on the basis of the data of period 4 in R8; Figure S3: phylogenetic analysis of the bacteria culture; Figure S4, S5, and S6: concentration of $\mathrm{NO}_{2}{ }^{-}, \mathrm{NH}_{4}{ }^{+}$, and $\mathrm{NO}_{3}{ }^{-}$ detected in the influent and effluent of each reactor; Figure S7, S8, and S9: pH monitored in the influent and effluent of each reactor.

\section{References}

1. Lackner, S.; Gilbert, E. M.; Vlaeminck, S. E.; Joss, A.; Horn, H.; van Loosdrecht, M. C., Full-scale partial nitritation/anammox experiences-An application survey. Water Res 2014, 55, 292-303.

2. Morales, N.; Rio, A. V. d.; Vazquez-Padin, J. R.; Mendez, R.; Mosquera-Corral, A.; Campos, J. L., Application of the Anammox process to the main stream of WWTPs. In 9th Edition Int. Symposium of Sanitary and Environmental, Sidisa, 2011.

3. Lotti, T.; Kleerebezem, R.; Hu, Z.; Kartal, B.; de Kreuk, M. K.; van Erp Taalman Kip, C.; Kruit, J.; Hendrickx, T. L. G.; van Loosdrecht, M. C. M., Pilot-scale evaluation of anammox-based mainstream nitrogen removal from municipal wastewater. Environ. Technol. 2015, 36, (9), 1167-1177.

4. van der Star, W. R.; Abma, W. R.; Blommers, D.; Mulder, J. W.; Tokutomi, T.; Strous, M.; Picioreanu, C.; van Loosdrecht, M. C., Startup of reactors for anoxic ammonium oxidation: experiences from the first full-scale anammox reactor in Rotterdam. Water Res. 2007, 41, (18), 4149-63. 
5. Lotti, T.; van der Star, W. R. L.; Kleerebezem, R.; Lubello, C.; van Loosdrecht, M. C. M., The effect of nitrite inhibition on the anammox process. Water Res. 2012, 46, (8), 2559-2569.

6. Carvajal-Arroyo, J. M.; Sun, W.; Sierra-Alvarez, R.; Field, J. A., Inhibition of anaerobic ammonium oxidizing (anammox) enrichment cultures by substrates, metabolites and common wastewater constituents. Chemosphere 2013, 91, (1), $22-7$.

7. Li, G.; Vilcherrez, D.; Carvajal-Arroyo, J. M.; Sierra-Alvarez, R.; Field, J. A., Exogenous nitrate attenuates nitrite toxicity to anaerobic ammonium oxidizing (anammox) bacteria. Chemosphere 2016, 144, 2360-2367.

8. Fernández, I.; Dosta, J.; Fajardo, C.; Campos, J. L.; Mosquera-Corral, A.; Méndez, R., Short- and long-term effects of ammonium and nitrite on the Anammox process. J. Environ. Manag. 2012, 95, Supplement, (0), S170-S174.

9. Puyol, D.; Carvajal-Arroyo, J. M.; Sierra-Alvarez, R.; Field, J. A., Nitrite (not free nitrous acid) is the main inhibitor of the anammox process at common $\mathrm{pH}$ conditions. Biotechnol. Lett. 2014, 36, (3), 547-51.

10. Carvajal-Arroyo, J. M.; Puyol, D.; Li, G.; Swartwout, A.; Sierra-Álvarez, R.; Field, J. A., Starved anammox cells are less resistant to inhibition. Water Res. 2014, 65, (0), 170-176.

11. Carvajal-Arroyo, J. M.; Puyol, D.; Li, G.; Sierra-Alvarez, R.; Field, J. A., The role of $\mathrm{pH}$ on the resistance of resting- and active anammox bacteria to NO inhibition. Biotechnol. Bioeng. 2014. 111, (10), 1949-56. 
12. Karlsson, R.; Karlsson, A.; Backman, O.; Johansson, B. R.; Hulth, S., Identification of key proteins involved in the anammox reaction. FEMS Microbiol. Lett. 2009, 297, (1), 87-94.

13. Carvajal-Arroyo, J. M.; Puyol, D.; Li, G.; Sierra-Álvarez, R.; Field, J. A., The intracellular proton gradient enables anaerobic ammonia oxidizing (anammox) bacteria to tolerate $\mathrm{NO}_{2}^{-}$inhibition. J. Biotechnol. 2014, 192, 265-267.

14. Speth, D. R.; in /'t Zandt, M. H.; Guerrero-Cruz, S.; Dutilh, B. E.; Jetten, M. S. M., Genome-based microbial ecology of anammox granules in a full-scale wastewater treatment system. Nat Commun 2016, 7.

15. Wood, N. J.; Alizadeh, T.; Richardson, D. J.; Ferguson, S. J.; Moir, J. W. B., Two domains of a dual-function NarK protein are required for nitrate uptake, the first step of denitrification in Paracoccus pantotrophus. Mol. Microbiol. 2002, 44, (1), 157-170.

16. Jia, W.; Cole, J. A., Nitrate and nitrite transport in Escherichia coli. Biochem. Soc. Trans. 2005, 33, 159-161.

17. Strous, M.; Pelletier, E.; Mangenot, S.; Rattei, T.; Lehner, A.; Taylor, M. W.; Horn, M.; Daims, H.; Bartol-Mavel, D.; Wincker, P.; Barbe, V.; Fonknechten, N.; Vallenet, D.; Segurens, B.; Schenowitz-Truong, C.; Medigue, C.; Collingro, A.; Snel, B.; Dutilh, B. E.; Op den Camp, H. J.; van der Drift, C.; Cirpus, I.; van de Pas-Schoonen, K. T.; Harhangi, H. R.; van Niftrik, L.; Schmid, M.; Keltjens, J.; van de Vossenberg, J.; Kartal, B.; Meier, H.; Frishman, D.; Huynen, M. A.; Mewes, H. W.; Weissenbach, J.; Jetten, M. S.; Wagner, M.; Le Paslier, D., 
Deciphering the evolution and metabolism of an anammox bacterium from a community genome. Nature 2006, 440, (7085), 790-4.

18. Goddard, A. D.; Moir, J. W.; Richardson, D. J.; Ferguson, S. J., Interdependence of two NarK domains in a fused nitrate/nitrite transporter. Mol. Microbiol. 2008, 70, (3), 667-81.

19. Gori, F.; Tringe, S. G.; Kartal, B.; Marchiori, E.; Jetten, M. S., The metagenomic basis of anammox metabolism in Candidatus 'Brocadia fulgida'. Biochem. Soc. Trans. 2011, 39, (6), 1799-804.

20. Kartal, B.; de Almeida, N. M.; Maalcke, W. J.; Op den Camp, H. J.; Jetten, M. S.; Keltjens, J. T., How to make a living from anaerobic ammonium oxidation. FEMS Microbiol. Rev. 2013, 37, (3), 428-61.

21. van de Vossenberg, J.; Woebken, D.; Maalcke, W. J.; Wessels, H. J.; Dutilh, B. E.; Kartal, B.; Janssen-Megens, E. M.; Roeselers, G.; Yan, J.; Speth, D.; Gloerich, J.; Geerts, W.; van der Biezen, E.; Pluk, W.; Francoijs, K. J.; Russ, L.; Lam, P.; Malfatti, S. A.; Tringe, S. G.; Haaijer, S. C.; Op den Camp, H. J.; Stunnenberg, H. G.; Amann, R.; Kuypers, M. M.; Jetten, M. S., The metagenome of the marine anammox bacterium 'Candidatus Scalindua profunda' illustrates the versatility of this globally important nitrogen cycle bacterium. Environ. Microbiol. 2013, 15, (5), 1275-89.

22. Zheng, H.; Wisedchaisri, G.; Gonen, T., Crystal structure of a nitrate/nitrite exchanger. Nature 2013, 497, (7451), 647-51. 
23. Chen, T.; Zheng, P.; Tang, C.; Wang, S.; Ding, S., Performance of ANAMMOX-EGSB reactor. Desalination 2011, 278, (1-3), 281-287.

24. Strous, M.; Heijnen, J. J.; Kuenen, J. G.; Jetten, M. S. M., The sequencing batch reactor as a powerful tool for the study of slowly growing anaerobic ammonium-oxidizing microorganisms. Appl. Microbiol. Biotechnol. 1998, 50, 589-596.

25. Puyol, D.; Carvajal-Arroyo, J. M.; Garcia, B.; Sierra-Alvarez, R.; Field, J. A., Kinetic characterization of Brocadia spp.-dominated anammox cultures. Bioresource Technol. 2013, 139C, 94-100.

26. Neef, A.; Amann, R.; Schlesner, H.; Schleifer, K.-H., Monitoring a widespread bacterial group: in situ detection of planctomycetes with 16S rRNA-targeted probes. Microbiol. 1998, 144, (12), 3257-3266.

27. Ferris, M. J.; Muyzer, G.; Ward, D. M., Denaturing gradient gel electrophoresis profiles of $16 \mathrm{~S}$ rRNA-defined populations inhabiting a hot spring microbial mat community. Appl. Environ. Microbiol. 1996, 62, (2), 340-346.

28. Rich, J. J.; Dale, O. R.; Song, B.; Ward, B. B., Anaerobic ammonium oxidation (Anammox) in Chesapeake Bay sediments. Microb. Ecol. 2007, 55, (2), 311-320.

29. Penton, C. R.; Devol, A. H.; Tiedje, J. M., Molecular Evidence for the Broad Distribution of Anaerobic Ammonium-Oxidizing Bacteria in Freshwater and Marine Sediments. Appl. Environ. Microbiol. 2006, 72, (10), 6829-6832. 
30. APHA, Standard methods for the examination of water and wastewater. Eaton, A. D., Clesceri, L. S., Rice, E. W., Greenberg, A. E., Eds., 21 $1^{\text {st }}$ Ed. Washington D.C. American Public Health Association: 2005.

31. Kuypers, M. M. M.; Sliekers, A. O.; Lavik, G.; Schmid, M.; Jorgensen, B. B.; Kuenen, J. G.; Sinninghe Damste, J. S.; Strous, M.; Jetten, M. S. M., Anaerobic ammonium oxidation by anammox bacteria in the Black Sea. Nature 2003, 422, (6932), 608-611.

32. Tamura, K.; Stecher, G.; Peterson, D.; Filipski, A.; Kumar, S., MEGA6: Molecular Evolutionary Genetics Analysis version 6.0. Mol. Biol. Evol. 2013, $30,(12), 2725-2729$.

33. Saitou, N.; Nei, M., The neighbor-joining method - A new method for reonstructing phylogenetic trees. Jpn. J. Genet. 1986, 61, (6), 611-611.

34. Felsenstein, J., Confidence-limits on phylogenies - An approach using the bootstrap. Evolution 1985, 39, (4), 783-791.

35. Tamura, K.; Nei, M.; Kumar, S., Prospects for inferring very large phylogenies by using the neighbor-joining method. Proc. Natl. Acad. Sci. U.S.A. 2004, 101, (30), 11030-11035.

36. Vanotti, M. B.; Szogi, A. A.; Rothrock, M. J. Novel anammox bacterium isolate. U.S. Patent application no. 13/013,874. U.S. Patent and Trademark Office, Washington, D.C. 2011. 
37. Carvajal-Arroyo, J. M.; Puyol, D.; Li, G.; Lucero-Acuña, A.; Sierra-Alvarez, R.; Field, J. A., Pre-exposure to nitrite in the absence of ammonium strongly inhibits anammox. Water Res. 2014, 48, (0), 52-60.

38. Kartal, B.; Maalcke, W. J.; Almeida, N. M. d.; Cirpus, I.; Gloerich, J.; Geerts, W.; Op de Camp, H. J. M.; Harhangi, H. R.; Janssen-Megens, E. M.; Francoijs, K.-J.; Stunnenberg, H. G.; Keltjens, J. T.; Jetten, M. S. M.; Strous, M., Molecular mechanism of anaerobic ammonium oxidation. Nature 2011, 479, (7371), 127-130.

39. van Niftrik, L.; Jetten, M. S., Anaerobic ammonium-oxidizing bacteria: unique microorganisms with exceptional properties. Microb. Mol. Bio. Rev. 2012, 76, (3), 585-96.

40. Driessen, W.; Yspeert, P., Anaerobic Treatment of Low, Medium and High Strength Effluent in the Agro-industry. Water Sci. Technol. 1999, 40, (8), 221-228 
Table 1. Summary of conditions applied to experiment protocols and the purposes.

\begin{tabular}{|c|c|c|c|c|c|c|c|c|}
\hline \multirow{2}{*}{\multicolumn{2}{|c|}{ Experiment }} & \multirow{2}{*}{ Purpose } & \multicolumn{6}{|c|}{$\begin{array}{l}\text { Period } \\
\left.\text { (N-compounds }(\mathrm{mM}): \mathrm{NO}_{2}^{-} / \mathrm{NH}_{4}^{+} / \mathrm{NO}_{3}^{-}\right)\end{array}$} \\
\hline & & & $\mathbf{P 1}$ & $\mathbf{P 2}$ & P3 & P4 & P5 & P6 \\
\hline \multirow[t]{4}{*}{$E 1^{*}$} & & & $0-13 d$ & $14-17 d$ & $18-20 d$ & $21-27 d$ & $28-32 d$ & $33-35 d$ \\
\hline & $\mathbf{R} \mathbf{1}^{* *}$ & Control: proper functioning reactor & $9.3 / 7.7 / 0$ & $9.3 / 7.7 / 0$ & $9.3 / 7.7 / 0$ & $9.3 / 7.7 / 0$ & $9.3 / 7.7 / 0$ & $9.3 / 7.7 / 0$ \\
\hline & $\mathbf{R} \mathbf{2}^{* *}$ & $\mathrm{NO}_{2}{ }^{-}$inhibition event followed by timely $\mathrm{NO}_{3}{ }^{-}$addition & $9.3 / 7.7 / 0$ & $9.3 / 0 / 0$ & $9.3 / 7.7 / 5.0$ & $9.3 / 7.7 / 0$ & $9.3 / 7.7 / 0$ & $9.3 / 7.7 / 0$ \\
\hline & $\mathbf{R} 3^{* *}$ & $\mathrm{NO}_{2}^{-}$inhibition event followed by delayed $\mathrm{NO}_{3}^{-}$addition & $9.3 / 7.7 / 0$ & $9.3 / 0 / 0$ & $9.3 / 7.7 / 0$ & $9.3 / 7.7 / 0$ & $9.3 / 7.7 / 5.0$ & $9.3 / 7.7 / 0$ \\
\hline \multirow[t]{4}{*}{$E 2^{*}$} & & & $0-16 d$ & $17-20 d$ & $21-23 d$ & 24-32d & $N A$ & $N A$ \\
\hline & $\mathbf{R} 4^{* *}$ & Control: proper functioning reactor & $9.3 / 7.7 / 0$ & $9.3 / 7.7 / 0$ & $9.3 / 7.7 / 0$ & $9.3 / 7.7 / 0$ & $N A$ & $N A$ \\
\hline & $\mathbf{R} 5^{* *}$ & $\begin{array}{l}\mathrm{NO}_{2}^{-} \text {inhibition event followed by timely addition of } \\
\text { different } \mathrm{NO}_{3}^{-} \text {conc. }\end{array}$ & $9.3 / 7.7 / 0$ & $9.3 / 0 / 0$ & $9.3 / 7.7 / 2.0$ & $9.3 / 7.7 / 0$ & $N A$ & $N A$ \\
\hline & $\mathbf{R} \mathbf{6}^{* *}$ & $\begin{array}{l}\mathrm{NO}_{2}^{-} \text {inhibition even followed by timely addition of } \\
\text { different } \mathrm{NO}_{3}^{-} \text {conc. }\end{array}$ & $9.3 / 7.7 / 0$ & $9.3 / 0 / 0$ & $9.3 / 7.7 / 3.3$ & $9.3 / 7.7 / 0$ & $N A$ & $N A$ \\
\hline \multirow[t]{4}{*}{$E 3^{*}$} & & & $0-17 d$ & $18-21 d$ & $22-27 d$ & $28-30 d$ & $N A$ & $N A$ \\
\hline & $\mathbf{R} 7^{* *}$ & Control: proper functioning reactor & $9.3 / 7.7 / 0$ & $9.3 / 7.7 / 0$ & $9.3 / 7.7 / 0$ & $9.3 / 7.7 / 0$ & $N A$ & $N A$ \\
\hline & $\mathbf{R} 8^{* *}$ & $\begin{array}{c}\mathrm{NO}_{2}^{-} \text {inhibition and potential } \mathrm{N}_{2} \text { production from other } \\
\text { microbial processes }\end{array}$ & $9.3 / 7.7 / 0$ & $9.3 / 0 / 0$ & $0 / 7.7 / 5.0$ & $9.3 / 7.7 / 0$ & $N A$ & $N A$ \\
\hline & $\mathbf{R 9} \mathbf{9}^{* *}$ & $\mathrm{NO}_{2}^{-}$inhibition event followed by short exposure to $\mathrm{NO}_{3}^{-}$ & $9.3 / 7.7 / 0$ & $9.3 / 0 / 0$ & $9.3 / 7.7 / 5.0(1 \mathrm{~d})$ & $9.3 / 7.7 / 0$ & $N A$ & $N A$ \\
\hline
\end{tabular}

${ }^{*} E 1, E 2$, and E3 indicate Experiment 1, 2, and 3, respectively;

${ }^{* *} R 1, R 2, R 3, R 4, R 5, R 6, R 7, R 8$, and $R 9$ indicate Reactor $1,2,3,4,5,6,7,8$, and 9, respectively;

NA, Not applicable. 


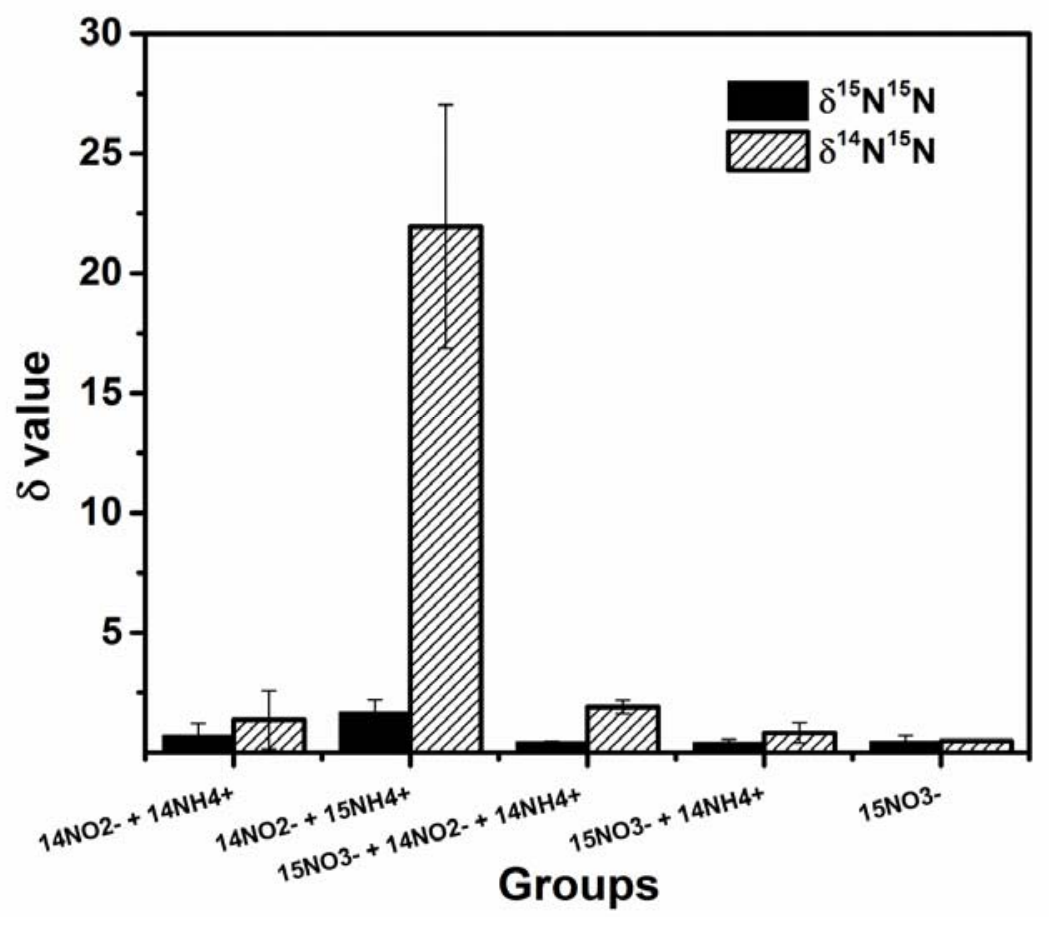

Figure 1. Evidence of anammox as the dominant biological reaction in the anammox granular sludge used in this study. $\delta$ value indicates the ratio of labeled dinitrogen gas detected in the sample and background. Anammox activity is expressed as anaerobic ${ }^{15} \mathrm{NH}_{4}^{+}$oxidation by ${ }^{14} \mathrm{NO}_{2}{ }^{-}$to ${ }^{14} \mathrm{~N}^{15} \mathrm{~N}$ (diagonal slashed bar), while denitrification potential was estimated by monitoring the production of ${ }^{15} \mathrm{~N}^{15} \mathrm{~N}$ (filled bar) from ${ }^{15} \mathrm{NO}_{3}{ }^{-}$either alone or in combination with ${ }^{14} \mathrm{NH}_{4}{ }^{+}$and/or ${ }^{14} \mathrm{NO}_{2}{ }^{-}$. Error bars (shown if lager than the symbols) represent standard deviations of duplicate assays. 


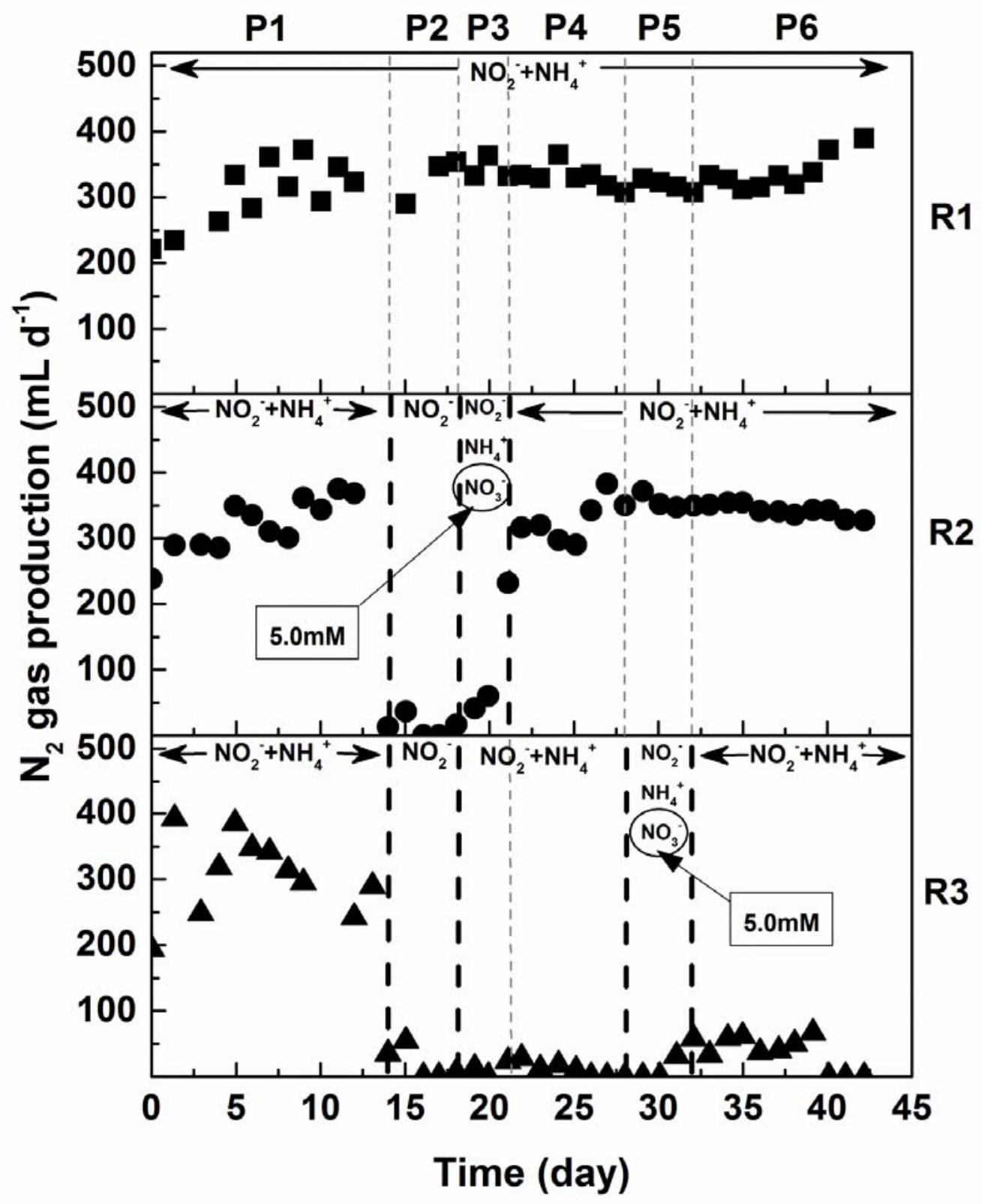

Figure 2. Effect of the timing of adding $\mathrm{NO}_{3}{ }^{-}$on the performance of UASB reactors subjected to $\mathrm{NO}_{2}{ }^{-}$inhibition caused by $\mathrm{NH}_{4}{ }^{+}$feed interruption. $\mathrm{R} 1$ was operated as the control reactor by supplying substrate $\left(9.3 \mathrm{mM} \mathrm{NO}_{2}^{-}\right.$and $\left.7.7 \mathrm{mM} \mathrm{NH}_{4}{ }^{+}\right)$in influent during the entire experimental time. $\mathrm{R} 2$ was designed to fail by exposing it to $9.3 \mathrm{mM} \mathrm{NO}_{2}^{-}$only in period $2 \mathrm{NH}_{4}{ }^{+}$ interruption), but exposure to $5.0 \mathrm{mM} \mathrm{NO}_{3}{ }^{-}$in period 3 fully restored the anammox reactor by relieving $\mathrm{NO}_{2}{ }^{-}$stress. $\mathrm{R} 3$ was also designed to fail in periods 3-4, by exposing it to $9.3 \mathrm{mM} \mathrm{NO}_{2}{ }^{-}$ 
only in period $2\left(\mathrm{NH}_{4}{ }^{+}\right.$interruption). Addition of $5.0 \mathrm{mM} \mathrm{NO}_{3}{ }^{-}$in period 5 did not allow for any substantial recovery of anammox in period 6 due to the excessive exposure to $\mathrm{NO}_{2}{ }^{-}$stress. The performance of UASB reactors is estimated by the evolution of the daily $\mathrm{N}_{2}$ production during different operation periods (P1 - 6) according to designated N-compounds supply shown in Fig. S3. 


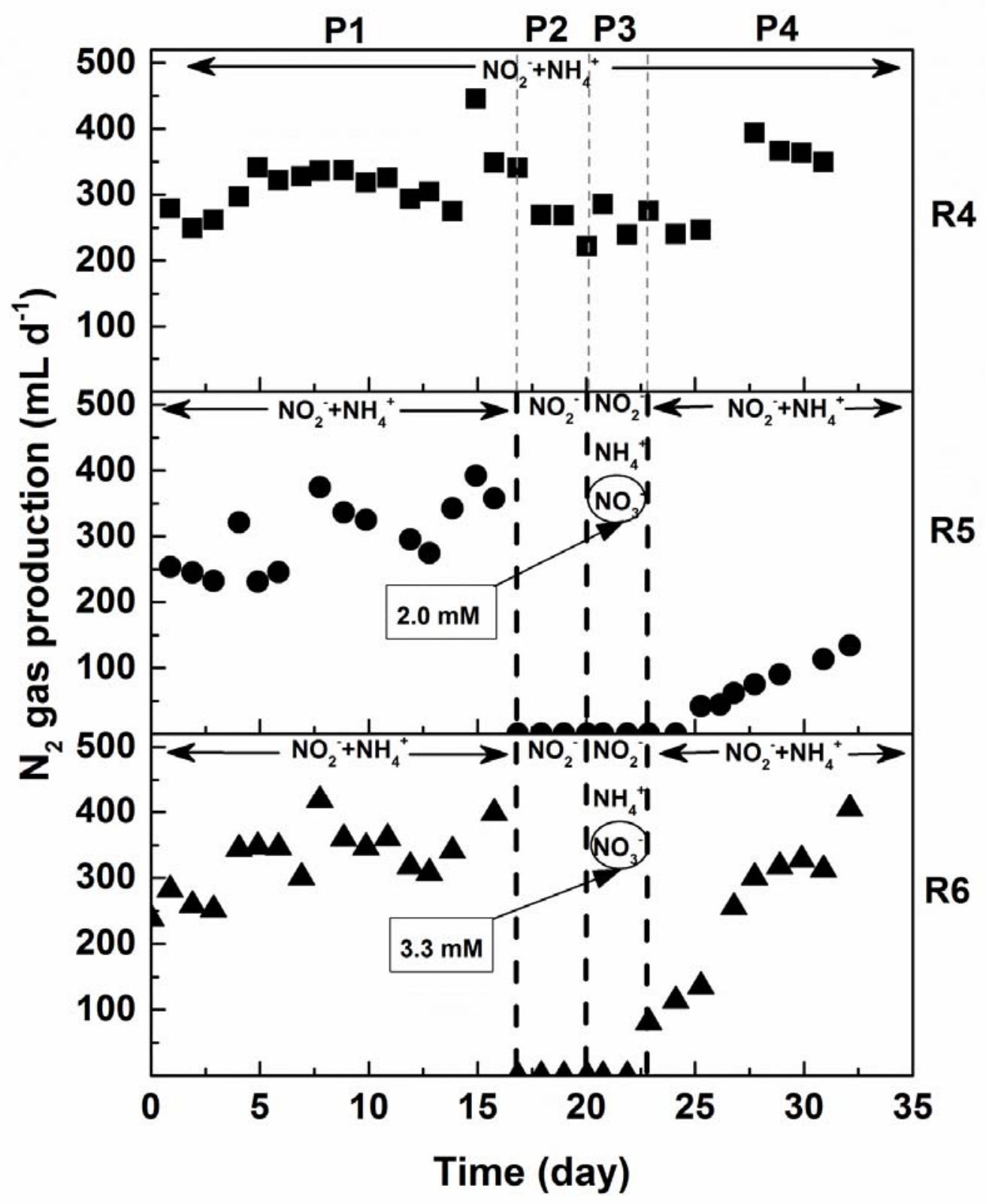

Figure 3. Effect of different $\mathrm{NO}_{3}{ }^{-}$concentrations $(2.0$ and $3.3 \mathrm{mM})$ on the performance of UASB reactors subjected to $\mathrm{NO}_{2}{ }^{-}$inhibition caused by $\mathrm{NH}_{4}{ }^{+}$interruption. $\mathrm{R} 4$ was operated as the control reactor by supplying substrate $\left(9.3 \mathrm{mM} \mathrm{NO}_{2}{ }^{-}\right.$and $\left.7.7 \mathrm{mM} \mathrm{NH}_{4}^{+}\right)$in influent during the entire experimental time. R5 was designed to fail by exposing it to $9.3 \mathrm{mM} \mathrm{NO}_{2}^{-}$only in period 2 $\left(\mathrm{NH}_{4}{ }^{+}\right.$interruption), but exposure to $2.0 \mathrm{mM} \mathrm{NO}_{3}{ }^{-}$in period 3 caused slow partial recovery of the anammox reactor by relieving $\mathrm{NO}_{2}^{-}$stress. $\mathrm{R} 6$ was also designed to fail by exposing it to $9.3 \mathrm{mM}$ 
$\mathrm{NO}_{2}{ }^{-}$only in period $2\left(\mathrm{NH}_{4}{ }^{+}\right.$interruption), but exposure to $3.3 \mathrm{mM} \mathrm{NO}_{3}{ }^{-}$in period 3 caused faster recovery of the anammox reactor by relieving $\mathrm{NO}_{2}{ }^{-}$stress, with the complete recovery observed at the end of experiment. The performance of UASB reactors is estimated by the evolution of the daily $\mathrm{N}_{2}$ production during different operation periods (P1 - 4) according to designated N-compounds supply showed in Fig. S4. 


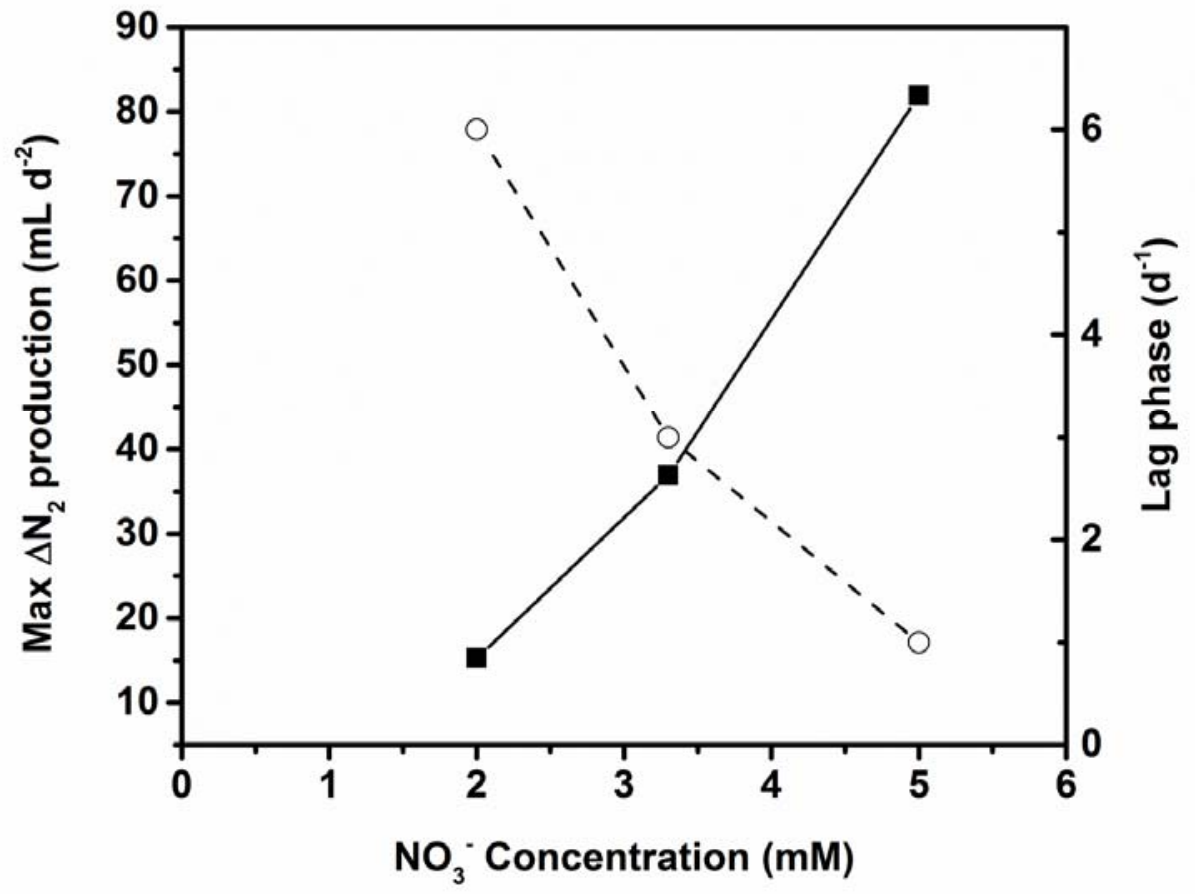

Figure 4. Correlation between $\mathrm{NO}_{3}{ }^{-}$concentrations and the rate of $\mathrm{N}_{2}$ productivity increase during the recovery $(\mathbf{m})$ or the lag phase $(\circ)$ since the time of $\mathrm{NO}_{3}{ }^{-}$addition. 


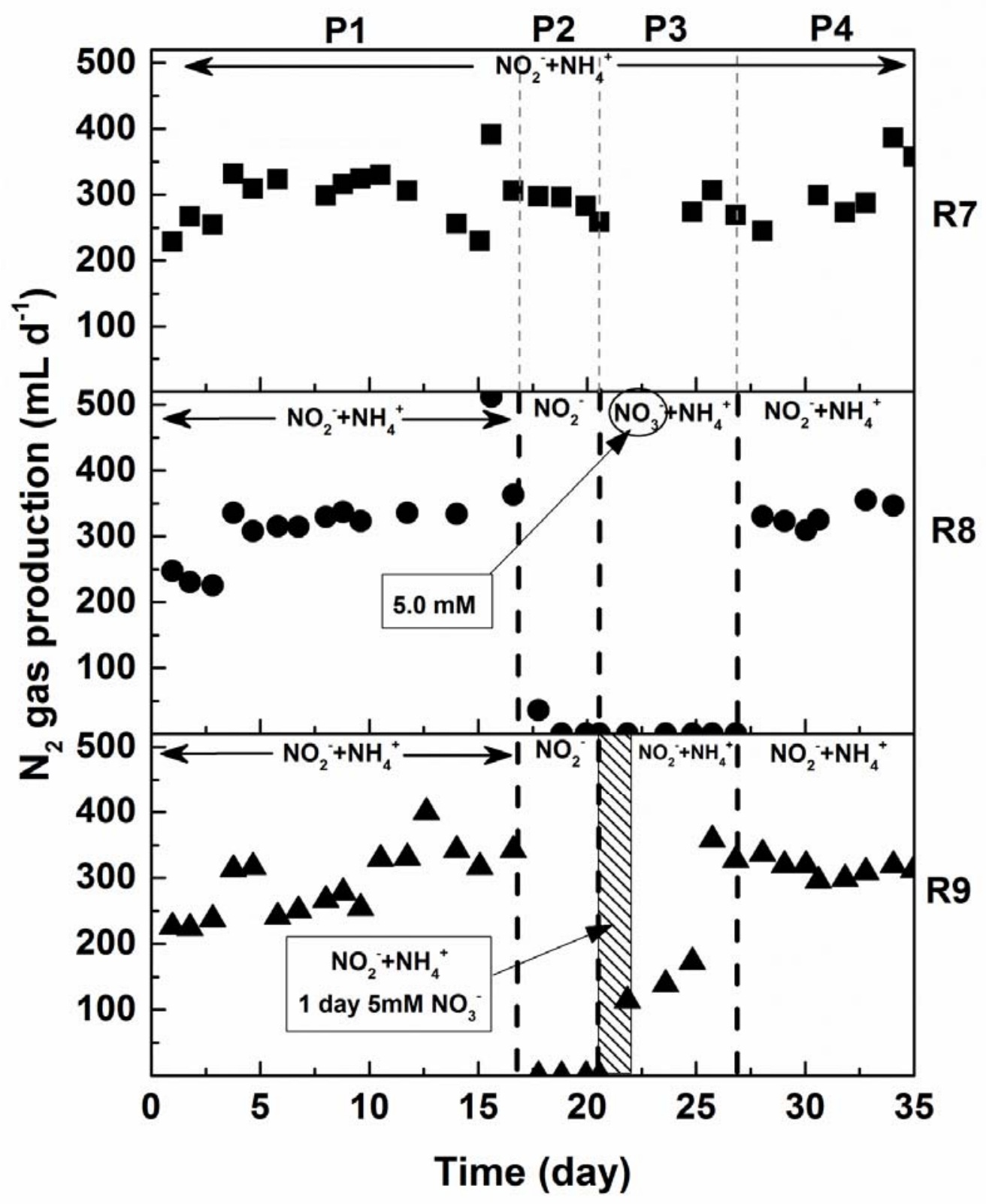

Figure 5. Demonstration of lack of denitrification potential (R8) and effect of short $\mathrm{NO}_{3}{ }^{-}$ incubation time (1 day at $5 \mathrm{mM}$ ) (R9) in recovering $\mathrm{NO}_{2}^{-}$inhibited anammox activity in UASB reactors subjected to $\mathrm{NO}_{2}{ }^{-}$inhibition caused by $\mathrm{NH}_{4}{ }^{+}$interruption. $\mathrm{R} 7$ was operated as the control reactor by supplying substrate $\left(9.3 \mathrm{mM} \mathrm{NO}_{2}{ }^{-}\right.$and $\left.7.7 \mathrm{mM} \mathrm{NH}_{4}{ }^{+}\right)$in influent during the entire experimental time. R8 was designed to fail by exposing it to $9.3 \mathrm{mM} \mathrm{NO}_{2}{ }^{-}$only in period 2 $\left(\mathrm{NH}_{4}{ }^{+}\right.$interruption), and exposure to $5.0 \mathrm{mM} \mathrm{NO}_{3}{ }^{-}$and $7.7 \mathrm{mM} \mathrm{NH}_{4}{ }^{+}$in period 3 caused 
undetectable $\mathrm{N}_{2}$ gas production due to the negligible denitrification in the granular anammox sludge used in this work and lack of ammonium since $\mathrm{NO}_{2}{ }^{-}$was excluded in period 3. Replacing $\mathrm{NO}_{3}{ }^{-}$for $\mathrm{NO}_{2}{ }^{-}$and maintaining $\mathrm{NH}_{4}{ }^{+}$in period 4 allowed for recovery of anammox due to $\mathrm{NO}_{2}{ }^{-}$ stress previously relieved by NO3- in period 3. R9 was also designed to fail by exposing it to 9.3 $\mathrm{mM} \mathrm{NO}_{2}{ }^{-}$only in period $2\left(\mathrm{NH}_{4}{ }^{+}\right.$interruption), but exposure to $5.0 \mathrm{mM} \mathrm{NO}_{3}{ }^{-}$for only 1 day in period 3 (shaded area) restored the anammox reactor by relieving $\mathrm{NO}_{2}{ }^{-}$stress, with the complete recovery observed in period 4 . The performance of UASB reactors is estimated by the evolution of the daily $\mathrm{N}_{2}$ production during different operation periods (P1 - 4) according to designated $\mathrm{N}$-compounds supply showed in Fig. S5. 


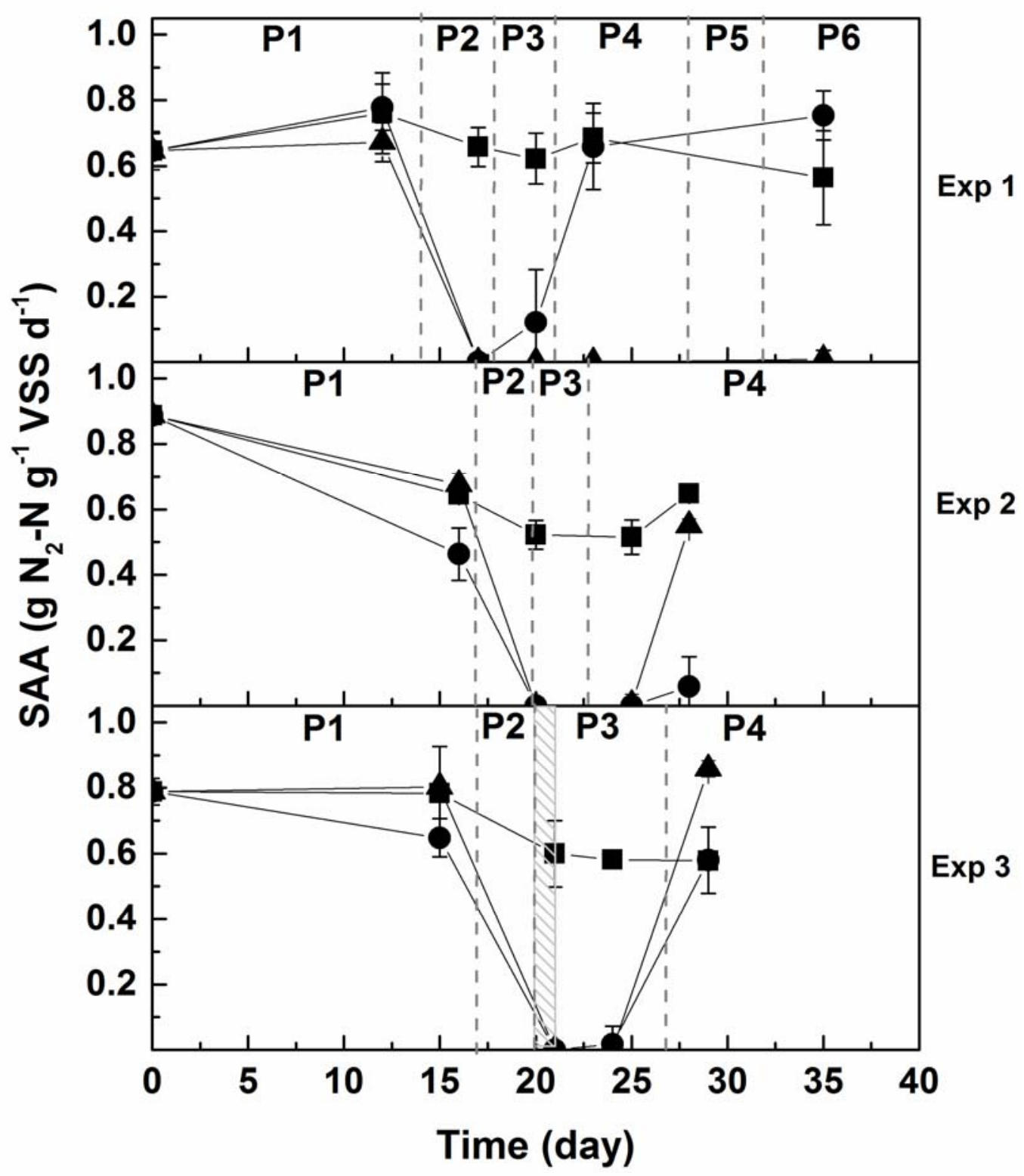

Figure 6. Evolution of the SAA of the biomass of the R1, R4 or R7 ( $\mathbf{})$, R2, R5 or R8 (•), and R3, R6 or R9 ( $\mathbf{\Delta})$ during different operation periods in three experiments, Experiments 1 (R1-R3), Experiment 2 (R4-R6) and Experiment 3 (R7-R9). Error bars (shown if lager than the symbols) represent standard deviations of duplicate assays. Details of the experiments are provided in Figures 2, 3 and 5 captions. 